\title{
An Impossible Possibility? Jewish Barthianism in Interwar Germany
}

\section{Introduction}

This essay seeks to add to our understanding of the different receptions of dialectical theology by examining the disputed exploration into the possibilities and limitations of the theological principles of Barthianism for the formulation of a Jewish theology in Germany of the 1930s.

The first decades of the twentieth century Germany saw an increasing suspicion of the nineteenth century's liberal faith in reason, progress and idealism. A decisive blow to liberalism and the Enlightenment worldview came with the all-encompassing devastation of World War I. In the theological atmosphere of the time, the urgency of the question of coram deo epitomized: How can God be present in our fallen, profane and sinful world? What is the ontological and existential meaning of God's absence? How can humanity find salvation? The resurgence of theological attitudes underscoring the radical breach between the divine and the world bespoke the growing sense of disenchantment and secularization of the modern world. ${ }^{1}$ The theological revolt against liberalism and the expression of a deep sense of opposition between the fallen world and divine transcendence found its emblematic Christian expression in Karl Barth and his theological circle - consisting of Emil Brunner, Rudolf Bultmann, Friedrich Gogarten, Eduard Thurneysen and others- who produced what is often called 'dialectical theology' or 'theology of crisis'.

\section{Karl Barth and Dialectical Theology}

In his formative years, Barth was deeply attentive to the trends of Protestant liberal theology and NeoKantianism, yet witnessing the broad mobilization of German academic theology to legitimate political

\footnotetext{
* I would like to thank Graham Ward for the extensive conversations on Barth, Judaism and Jews, as well as for his valuable comments on an earlier draft of this article.

${ }^{1}$ Benjamin Lazier, God Interrupted: Heresy and the European Imagination Between the World Wars (Princeton: Princeton University Press, 2012), 67-110.
} 
agendas surrounding the outbreak of the Great War disillusioned him beyond repair. ${ }^{2}$ This led him to seek to recover the absoluteness of the Word of God from within the severely distorting layers of human projection. Appalled by the liberal Kulturprotestantismus ideal, its prioritization of the religious subject, human experience, and the identification of the theological message with culture, ethics, or history, Barth published his Römerbrief (1919, revised second edition 1922) - presenting an extreme account of divine aseity and a strict opposition, indeed contradiction, between God and world. "The relation between our 'life in the world' and our "life in God", he wrote, "is one of "utter contrast"". ${ }^{3}$ Famous is his claim that "If I have a 'system' then it consists in the fact that I keep what Kierkegaard has called the 'infinite qualitative difference' between time and eternity consistently in mind. God is in heaven and you on earth". 4

Complementing the radical expulsion of God from the world, Barth upholds a strict conception of revelation. His entire theology pivots on the insight that "at the beginning of all knowledge of God stands not human self-acknowledgement but God's own knowing, man's being known by God, that is, revelation." ${ }^{, 5}$ Nothing could be said of God until God reveals himself, and anything said of God must derive solely from revelation. That revelation is God's own affair situates theology in a rather unstable indeed, dialectical - position: it seeks to speak of God but cannot, yet may speak of God only once God had made himself known. For Barth, the revealed word of God is irreducible to anything within human capacity and cuts through all layers of our familiar world. Theology therefore is completely autonomous and categorically distinct from any other field of human knowledge.

\footnotetext{
${ }^{2}$ Karl Barth, The Humanity of God, trans. Thomas Weiser (Richmond, Va.: John Knox Press, 1960), 14, although this account requires nuance. See: Gary Dorrien, The Barthian Revolt in Modern Theology (Lousiville: Westminster John Knox Press, 2000).

${ }^{3}$ See Barth's response to Harnack's "Fifteen Questions to the Despisers of Scientific Theology", entitled "Fifteen Answers to Professor Adolf von Harnack" in H. Martin Rumscheidt, Revelation and Theology: An Analysis of the Barth-Harnack correspondence of 1923 (Cambridge: Cambridge University Press, 1972), 33.

${ }^{4}$ Karl Barth, The Epistle to the Romans, (second edition) trans. Edwyn C. Hoskyns (London: Oxford University Press, 1968), xiii. On the crucial impact of Kierkegaard on Barth in those early years: Thomas F. Torrance, Karl Barth: An Introduction to his Early Theology, 1910-1931 (London: SCM Press, 1962), 44-7.

${ }^{5}$ Karl Barth, The Theology of the Reformed Confessions, trans. Darrell L. Guder and Judith J. Guder (Louisville: Westminster John Knox Press, 2005), 65.
} 
It is essential to Barth that God's absolute transcendence and otherness is not compromised by revelation. Rather, the paradoxical insight into an unknowable God is made possible by the fact that God has 'taken flesh' in Christ, who crossed the threshold into historical actuality and safeguards God from entering it. While the Gospel is not itself revelation, it bears witness to the revelation in Christ, and thus holds unmatchable importance for Barth's biblically-oriented theology. Of course, in line with Paul, Augustine, Luther and much of Christian tradition, Barth saw a stark opposition between Gospel and Law: the law cannot show the believer the path to God. The message of the Gospel is clear: "the Gospel proclaims a God utterly distinct from men", and it is the task of the church to proclaim this message. ${ }^{6}$

Before we turn to examine Jewish attempts at grappling with Barth's radical thought, we must first consider a number of its theological implications that will be relevant to our discussion. First, the position of analogia entis is rejected as idolatrous; nothing implicit in our humanity links us to God. The creatureliness of humans manifests not a continuum, but a severe distinction from the Creator. We have a natural antagonism toward God which needs to be overcome before openness to God can emerge. Second, revelation, atonement and salvation are interconnected categories, representing different sides of the single event of reconciliation with God wherein one purges herself of her godforsaken existence. In this stage of his thinking, Barth held an existential view (absent in his later writings) according to which one's finite, sinful existence is contrasted with the absoluteness of the divine, and the openness to the Word of God is made by an existential act of resolute decision in the moment. Thus knowledge of God is one with the event of revelation and salvation. Third, Barth's theology is committed to a complete devaluation of history. Both history and human culture in it are entirely purged from God's presence. As a relentless reaction to nineteenth century historicism, the value of history as the possible site of ultimate meaning is abolished in Barth's scheme. History for him is merely the recording of humanity's "falling away from

\footnotetext{
${ }^{6}$ Barth, Romans, 28.
} 
God"; 7 it is the plane upon which struggle, power and trivial events occur; "yet one drop of eternity is of greater weight than a vast ocean of finite things". 8

\section{Weimar Jews and Dialectical Theology}

The historical background for the Jewish engagement with Barthianism is essential to rightfully understand the theological content of this engagement as well as the stakes involved. The denunciation of the $19^{\text {th }}$ century liberal theology was shared by many Jews who were too disillusioned by the promises and optimism of liberalism and particularly repelled by the relativism and historicism bequeathed to them. ${ }^{9}$ Many young Jewish thinkers wished to liberate themselves from the shackles of the synthesis of Kantianism and Judaism that characterized the Jewish liberal tradition and overcome the overall conflation of Judaism with the values of the enlightenment so carefully fashioned by Jewish thinkers such as Hermann Cohen. The arduous project of nineteenth century Jewish apologetics to present Judaism as the root of the prevailing values and thus to indicate its legitimacy for modernity was now seen as a surrendering of authenticity for the sake of acceptance. Moreover, the unsteady status of Jewish existence in Weimar Germany motivated a process of dissimilation and revival of Jewish self-consciousness. ${ }^{10}$ This process consisted of, among others, the desire to explain and articulate the uniqueness and particularity of Judaism vis-à-vis its surrounding environment in a manner appropriate to the contemporary spiritual condition.

\footnotetext{
${ }^{7}$ Karl Barth, Die theologie Zwinglis 1922/1923. Vorlesungen Göttingen Wintersemester 1922/1923 (Zurich: TVZ, 2004), 48. Quoted in John Webster, Barth's Earlier Theology: Four Studies (New York: T\&T Clark, 2005), 23.

${ }^{8}$ Barth, Romans, 77.

${ }^{9}$ For an overview of the theological currents of the time: Alexander Altmann, "Theology in Twentieth Century German Jewry", Leo Baeck Institute Yearbook 1, no. 1 (1956): 201; Peter E. Gordon, "Weimar Theology: From Historicism to Crisis", Weimar Thought: A Contested Legacy, eds. Peter E. Gordon and John P. McCormick (Princeton: Princeton University Press, 2013), 150-78. On anti-historicism of major German-Jewish thinkers: David N. Myers, Resisting History: Historicism and its Discontents in German-Jewish Thought (Princeton: Princeton University Press 2003).

${ }^{10}$ Michael Brenner, The Renaissance of Jewish Culture in Weimar Germany (New Haven: Yale University Press, 1996).
} 
As the most impactful theological movement in interwar Germany, dialectical theology became a reference point for various Jewish inquiries. ${ }^{11}$ Barth's Römerbrief was accepted as an epoch making work - as the Jüdisches Lexikon specified, this work and "the movement linked to Gogarten's dialectical theology" is "the last phase of Christian dogma". ${ }^{12}$ And within this historical and conceptual context, the Barthian school seemed to provide an exceptionally compelling theological model. It offered a profound rejoinder to the spiritual needs of the time, shared by Jews as well: it promoted a theological programme emphatically divorced from the synthetic liberal framework, it upheld a strict account of divine transcendence, and its uncompromising attitude toward the autonomy of religion were all seen as aptly countering the compromising tendencies of liberal theology.

Yet alongside its appeal, Barthianism posed some weighty hindrances from a Jewish point of view. We can identify these hindrances as pertaining to its origin, method, and content. Barth's movement, as stated, was a robust rejection of the liberal synthesis of Christianity and culture. The equivalent Jewish move, however, did not only seek to discard the liberal compromising of divinity, but was framed as a denunciation of foreign and ill-suited Protestant conceptuality internalized into Judaism. To turn once again to a Protestant theological school as a source for authentic Jewish expression would indeed be selfdefeating, merely perpetuating the liberal shortcoming intended to be fixed. Moreover, could - and indeed, should - the dogmatic nature of dialectical theology and its particular vocabulary be transposed into a Jewish discourse? And can Judaism accept the radical precepts it proposed?

\footnotetext{
${ }^{11}$ Lazier discusses the appeal and challenge posed to the Jewish thinkers Hans Jonas, Leo Strauss and Gershom Scholem by the recrudescence of 'Gnostic' impulses in interwar Germany in which Karl Barth played an important role. Benjamin Lazier, God Interrupted: Heresy and the European Imagination Between the World Wars (Princeton: Princeton University Press, 2012). On Barth's influence on the development of Strauss's thinking: Samuel Moyn, "From Experience to Law: Leo Strass and the Weimar Crisis of the Philosophy of Religion" History of European Ideas 33, no. 2 (2007):174-94. Comparisons between Franz Rosenzweig and Barth have also been made: Randi Rashkover, Revelation and Theopolitics: Barth, Rosenzweig and the Politics of Praise (New York: T\& T Clark, 2005); Moyn's Origins of the Other: Emmanuel Levinas Between Revelation and Ethics (London: Cornell University Press, 2006). And also: Benjamin Pollock, Franz Rosenzweig's Conversions: World Denial and World Redemption (Bloomington \& Indianapolis: Indiana University Press, 2014). And see note 48 below.
} 12
"Christentum" in Jüdisches
Lexikon,
1383.
http://sammlungen.ub.uni- frankfurt.de/freimann/content/pageview/363066. 
The order of our discussion will be as follows: First, Rabbi Max Wiener's moderate engagement with dialectical theology will be considered. Then we will explore Hans Joachim Schoeps's enthusiastic embracing of Barthianism. Next we will survey and analyze the various critical responses this position elicited. Finally, Alexander Altmann's response to Wiener, Schoeps and Barth, as well as the competing theology he formulated will be examined.

One final prefatory note is due. The Jewish thinkers discussed below rarely differentiated between the various theologians and views affiliated with the movement of dialectical theology. Most often, the account they confronted was its most radical version, i.e., Karl Barth's. This is not to say they had a cursory familiarity with the movement. As we shall see, the Jewish investigation into its possible fruitfulness will touch upon its more broad Christian layers and some of the general theses publically associate with it, but also with the unique minutiae of its programme. Yet it should be remembered that their main aim was not to comment on the doctrinal nuances and intricacies of this movement but to examine, as a whole, its possible bearings on Judaism; hence Barthianism and dialectical theology were, as a general rule, taken to be synonymous.

\section{Max Wiener}

An important attempt to make use of the new theological vocabulary for Jewish purposes was made by Max Wiener, a liberal rabbi who grew steadily opposed the liberal Weltanschauung. ${ }^{13}$ Wiener believed there is much Judaism can learn from dialectical theology, and developed a revelation-centered Jewish theology with clear irrational overtones. For him, the Jewish emphasis on the "impenetrability and inaccessibility" of God "makes the so-called dialectical theology interesting for us Jews". ${ }^{14}$ Weiner asks

\footnotetext{
${ }^{13}$ On Wiener, see Robert S. Schine, Jewish Thought Adrift: Max Wiener (1882-1950), (Atlanta: Scholars Press, 1992), especially 158-61. Wiener is the author of the celebrated Jüdische Religion im Zeitalter der Emanzipation (Berlin: Philo Verlag, 1933), an analysis of (primarily) post-emancipatory German Judaism. See Ehud Luz, "Max Wiener as a Historian of Jewish Religion in the Emancipation Period", Hebrew Union College Annual 56 (1985): 29-46 (Hebrew).

${ }^{14}$ Max Wiener, "Begriff und Aufgabe der jüdischen Theologie", Monatsschrift für Geschichte und Wissenschaft des Judentums 77 (1933) [henceforth BA].
} 
not whether, but "what and to what extent" should theological insights be drawn from the Protestant movement. ${ }^{15}$ Following Barth's lead, Wiener insists on a clear distinction between all fields of human endeavor and theology. To attempt talking about God with familiar categories would reach an inevitable failure: "one cannot speak about God and his appeal [Rede] to humans or about sin within the same horizon [Schicht] of terms" (BA 4) as other mundane human affairs. In a recognizable rhetoric, Wiener demands that inasmuch as Jewish theology seeks to "preserve the unique significance of its subjectmatter", it must proceed from "the fact of revelation" alone (BA 5). Judaism can be informed by dialectical theology's insistence that "all human reflection, and thus theological reflection as well, is deflected by the barrier that God the unattainable is for humans unless he presents himself, reveals [himself]" (BA 5). Nothing of God is readily available to us humans - "knowledge of divine things", Wiener posits, "is based on the concept of revelation" (BA 3). And since God is completely removed from the world, the "intrusion [Einbruch] of God's self-revealing" (BA 4) is a "dialectical process" and a “paradox".

Barth's claim, furthermore, that the task of theology is to preach and articulate the word of God as proclaimed in the Gospel plainly resonates with the task of Jewish theology, which is, in Wiener's view, to interpret and explain God's revelation as expressed in the Hebrew bible. Echoing Barth's cautioning, Wiener also warns against confusing Scripture with revelation. The Hebrew bible serves as the witness and bearer of the divine message, but it is not revelation itself - "the book that contains the Word of God is not necessarily identical with God's Word" (BA 6).

Alongside these points, it is also clear that Wiener is well aware that there is a limit to the commonalities between Judaism and Barthianism. While promoting "the primordial conception of biblical-Jewish religion", Wiener stresses that its understanding "hinges on certain historical highlights" (TP 465), in particular, the event of divine self-revelation at Mount Sinai. The concept of pure revelation advanced by

\footnotetext{
${ }^{15}$ Max Wiener, Theologische Probleme im Judentum, aus der Tagung des Allgemeinen Rabbinerverbandes (15. and 16. November)', Jüdische Rundschau 37 (1932): 465-6 [henceforth TP].
} 
dialectical theology, Wiener recognized further, is discordant with the Jewish understanding of this event, according to which the revelation at Sinai conveyed specific and concrete content to a specific and concrete people: the Jewish law was given to the Jewish people. Judaism "stands and falls with the commitment to the nucleus of this revelation, carried throughout all biblical-Jewish history, the covenant of the almighty living God with the people of Israel" (TP 465). For Wiener, Jewish theology rests on two fundamental and essential pillars: revelation and Jewish peoplehood. Indeed, throughout his Barthian exploration, Wiener remains staunchly aware of the need to retain the particularity of Judaism and Jewish theology. ${ }^{16}$ This does not mean that Judaism is completely particularistic - for Wiener there is an implicit tension between its religious-ethical universalism and its particularistic character. Nor does this imply that in Judaism the law occupies the "freed place of 'theology' in the overall system" (BA 10), but it is "a meaning-giving condition and requirement". Wiener finds dialectical theology a valuable source for the necessary alterations needed for a genuine Jewish theology. Yet he appreciates both its productivity and its limitations. In Wiener's adaptation of the Barthian approach, three important differences stand out: first, the announcement of a particular content of revelation, namely, Jewish law. Second, the location of quintessential moment of divine self-revelation in an actual historical event - the Sinaitic revelation. Third, the stress on peoplehood as the ultimate addressees of revelation. And yet it is apparent that Wiener believed that Karl Barth offers an opportunity for Judaism to unveil and express the true nature of its principles and teachings. At the same time, what Wiener took to be the true teachings of Judaism, such as the paradoxical nature of revelation, seems to be deeply impacted by Barth's views.

It is important to observe that by raising the question of "what and to what extent" Judaism could benefit from dialectical theology, Wiener reveals a fundamental presupposition: that one can differentiate between theological moments in Barth that are, as it were, 'neutral', i.e., not charged with inherently Christian resonances and are hence potentially adoptable by a Jewish approach, and theological themes

${ }^{16}$ This overall view is already stated in an earlier essay from 1923-1924 - Max Weiner "Jüdische Frömmigkeit und religiöses Dogma", Monatsschrift für Geschichte und Wissenschaft des Judentums 67 (1923): 153-67; 225-44; (1924):27-47. 
that are well-established within the Christian tradition and hence have no room in an authentic Jewish theology. To assume the neutrality of certain theological tenets permits interchange of ideas from Christianity to Judaism without jeopardizing the latter's integrity and authenticity. Thus Wiener believed that the Barthian attitude undergirding the radical otherness of God, for example, is similar to the motivation behind Maimonides' doctrine of negative attributes. As we shall see, a latent debate over the soundness of Wiener's fundamental presupposition with respect to Barthianism will animate the Jewish engagement with it as a whole. What is at stake, it should be stressed, is not only whether Jews can at all be 'Barthians' and what exactly this designation comes to mean. But more fundamentally, whether or not Jewish Barthianism is an impossible possibility touches upon the very nature of the language of theology as particularistic endeavor. What is at stake in this case, therefore, is the defining boundaries between Judaism and Christianity and the possibility of authentic self-assertion of either confession. As we shall see, different thinkers understood Barthianism in differing ways, manifesting the way in which the debate over dialectical theology served as a site for projecting the Jewish-Christian difference.

\section{Hans Joachim Schoeps}

If Wiener negotiated between the appeal of Barthianism and his commitment to a specific account of Judaism, Hans Joachim Schoeps, undoubtedly the most extreme example of a Jewish Barthianism in the interwar period, embraced the principles of dialectical theology with marked enthusiasm. Deeply imbibed in Protestant theology, the young and idiosyncratic Schoeps embarked on a theological task aimed at combating what he found to be a ubiquitous spiritual crisis, seizing Jews and Christians alike. The primary and central outcome of this effort, his book Jüdischer Glauber in dieser Zeit. Prolegomena zur Grundlegung einer systematischen Theologie des Judentums (1932) is a condensed and audacious attempt 
to lay the groundwork for a new systematic Jewish theology anchored primarily in Karl Barth's teachings. ${ }^{17}$

In Schoeps's diagnosis, a long process of apostasy and secularization has wreaked havoc in the heutigen Daseinsverständnis of the modern person. Jews and Christians alike have completely assimilated the "western history of fallenness" characterized by "the practical and theoretical elimination of Godconsciousness" (JG 84-85). The hallmark of this religious perversion is nineteenth century liberal theology against whom Schoeps levels a devastating admonishment. To express the travesty of the liberal framework, Schoeps quotes Emil Brunner's depiction of the modern conception of revelation, wherein revelation is "something generally timeless: the general 'wonder' of the natural order, the general 'wonder' of spiritual legalism, humanity, morality [Sittlichkeit], idea and ideality” (JG 1-2). ${ }^{18}$ Against this misconception and its resulted spiritual aberration, Schoeps sought to prompt a spiritual revolution by providing a theological systemization of Judaism that will ultimately implore the perplexed GermanJewry to abandon its Godless existence and, in a massive act of repentance [teshuvah], embrace the authentic Jewish life.

Schoeps does not restrict the task of spiritual revival to Jewish circles alone, however, for he believed that the harms of liberal theology and the hubristic traditions of rational discourses have deeply marred Christianity as well. Thus the current - and shared - mission of both Synagogue and Church is "to bring [their] preaching to the world that God is the Lord and that the world [...] is subjected to judgment" (JG 3). The Church and the Synagogue must preach their proclamation and lead people from their existence as 'heathens' to people of faith. In this respect, Schoeps admits, the Church is already a few steps ahead. Significant developments have taken place in Protestant theology, he notes, wherein for "the 15 years [...] such an in-depth reflection" has "become effective in the output of Karl Barth called "dialectical theology" (JG 3). This positive development underscores the urgent need for an equivalent Jewish

\footnotetext{
${ }^{17}$ Hans Joachim Schoeps, Jüdischer Glauber in dieser Zeit. Prolegomena zur Grundlegung einer systematischen Theologie des Judentums, (Tübingen, 1932) [henceforth JG].

${ }^{18}$ From: Emil Brunner, Der Mittler, (Tübingen, 1927) 19.
} 
undertaking that will inquire into "the reality of the fact of revelation". As a theological prolegomena, Schoeps proposes an "unbinding sketch" (JG 70) of the foundations of doctrines of faith, which include four fundamental biblical dogmas: the uniqueness of God, the Creation of the world ex nihilo (which is emphasized in particular), the revelation of the law of salvation and divine retribution.

In Schoeps's view, conducting a Jewish theology along the lines set forth by Barth is the only way to revitalize modern German Jewry. Thus, in a clear Barthian tone, Schoeps reveals his fundamental premises: Only "the Word of God itself, which is available to no man" (JG 5), erupting completely voluntarily, can provide a satisfactory departure point. Otherwise, "no theology will ever be anything other than human reflection on the subject of Jewish doctrine, on 'the Word of God' and human discourse about it" (ibid). Barth's theology is the prototype for the required Jewish theological endeavor, one which presupposes the radical gulf between God and man, is grounded in revelation and is thus non-rational and anti-historical in nature. Also Schoep's understanding of revelation bears conspicuous Protestant features. Indeed, blurring the traditional boundaries between Judaism and Christianity characterizes Schoeps's thought as a whole. He would later reflect that his "entire existential structure has always been a Protestant and Lutheran one. But I also have [...] the heritage of the Israelite prophets in my blood". ${ }^{19}$ Revelation, according to him, is "an experience of grace in which God opens up a possibility of salvation to the fallen ones" (JG 75). Adapting Barth's view into a Jewish context, the irrational biblical event of God's self-revealing on Sinai is taken as the moment of revelation and redemption; it is the event in which the salvific character of the revealed Word of God is manifested. Revelation is also "in the narrowest sense the legalizing declaration of the salvific will of God at Sinai as salvific law" (ibid), yet

\footnotetext{
${ }^{19}$ Hans Joachim Schoeps, Ja-Nein-und Trotzdem: Erinnerungen, Begegnungen, Erfahrungen (Mainz: Hase \& Koehler Verlag, 1974), 138; Gary Lease, 'Odd Fellows' in the Politics of Religion: Modernism, National Socialism and German Judaism (Berlin/New York: Mouton de Gruyter, 1995) 191-231. In Encyclopedia Judaica's entry on 'Schoeps, Hans-Joachim', it is stated that he "bring[s] Judaism very close to Christianity but stop[s] short of baptism", Encyclopedia Judaica vol. 14 (Jerusalem: Macmillan, 1971), 991. On the relation between Judaism and Christianity in Schoeps: Marc A. Krell, "Schoeps vs. Rosenzweig: Transcending Religious Borders", Zeitschrift für Religions- und Geistesgeschichte 52, no. 1 (2000): 25-37, later incorporated into his Intersecting Pathways: Modern Jewish Theologians in Conversation with Christianity (Oxford: Oxford University Press, 2003); Shaul Magid, Hasidism Incarnate: Hasidism, Christianity, and the Construction of Modern Judaism (Stanford: Stanford University Press, 2015) 141-47.
} 
this law is strictly biblical and indeed amorphous; Schoeps forcefully denies the validity of Jewish tradition and the oral torah. Consequently he minimizes the status of history as much as possible, abolishing its religious significance but stopping short solely at the revelatory event on Sinai. For him revelation alone, i.e., the willed self-revealing of God as an isolated and enclosed moment bears ultimate and exclusive authority. All human endeavors, limited in horizon, finite in capability, and deeply infected by $\sin$, are ill-based for the pursuit of divine truth.

We can see that for Schoeps, the differences in core theological precepts between Christianity and Judaism, as well as of the mission of the Church and the Synagogue, are reduced to the utmost minimum. The Christian nature of Barth's scheme is not denied, but neither does it seem to pose any serious hindrances for its application in a purported Jewish theology. That Barth provides for Jews the primary model to reestablish their faith and authentic Jewish life demonstrates how 'Barthian' Judaism in truth is. As part of his effort to establish Judaism as a biblical revelatory religion, Schoeps claims to uncover a counter-history within Judaism, marshaled by thinkers including Judah Halevi, Chasdi Crescas, and Salomon Ludwig Steinheim, who appreciate the non-rational nature of its revelation. Steinheim, to whom Schoeps felt a particular bond, is portrayed as a proto-Barthian. To be a Jewish Barthian means for Schoeps, in effect, to be truly Jewish. The near-conflation between the two is, as we have seen, a step Wiener would not take.

\section{Jewish Anti-Barthianism: Responses to Schoeps}

Schoeps's wholesale affiliation with Karl Barth and his adaptation of the radical Protestant scheme to Jewish purposes drew numerous Jewish responses. ${ }^{20}$ These responses, as we shall now see, identified and contested a number of disputable points and suppositions in Schoep's position and as such offer an important lens into the attraction and retraction of Barthian theology from a Jewish perspective.

\footnotetext{
${ }^{20}$ See also Ernst Simon's review of Max Wiener's emancipation book, where he notes Schoeps's erudition but also clearly opposes his theology. Ernst Simon, "Hadat Shel Ha'Ratzionalismus" ["The Religion of Rationalism"], Moznaim 3 no.1-6 (1934/1935):110-13 [Hebrew]. Schine states that Schoeps "drew protest [...] from the orthodox camp" (Schine, Jewish Thought Adrift, 100), yet as we shall see, the protest was drawn from wider Jewish circles.
} 
The first response to Schoeps's Jüdischer was penned by Ludwig Feuchtwanger, the editor of the Bayerischen Israelitische Gemeindezeitung from 1930 to 1938, only a few months after its appearance. ${ }^{21}$ Bemoaning the deep Christian tone of Schoeps's book, Feuchtwanger maintains that dogmatic theology sits uneasily with Judaism. Notwithstanding externally-compelled occasions, Jews were spared the burden of systemizing their faith. The increased threat of assimilation in modern times prompted for the first time an internal impetus to organize and systematize Judaism. The problem with the attempts to do so is their repeated tendency to utilize categories and methods from the 'outside'. A theological account of Judaism based on Jewish standards is yet to be found. In this respect, Schoeps's endeavor to establish a new systematic theology of Judaism "in the path and in the sacred language of Karl Barth, Emil Brunner, Gogarten" (DV 166) follows this lamentable trend. Just as nineteenth century Jewish thinkers, against whom Schoeps forcefully reacts, emulated the liberal impulses of Christian theology, he too reproduces the same lapse by following Karl Barth's track. But it is not only the foreign source that renders Schoeps's project problematic. As Feuchtwanger makes clear, in importing the "vocabulary and grammar" of dialectical theology, one takes in also its Lutheran and Calvinist impulses. "Schoeps is plainly captivated by the literary product of anti-liberal Protestantism", yet applying it in order to spawn a Jewish renewal is, according to Feuchtwanger, "simply an aberration [ein Irrweg schlechthin]" (DV 167). While not entering into specifics, Feuchtwanger determines that dialectical theology in its entirety is profoundly colored by Protestant sensitivities and as such cannot serve as a source for any Jewish theological effort.

A couple of months later Gerhard (Gershom) Scholem, handed Feuchtwanger a short piece entitled 'Open Letter to the Author of the Monograph Jüdischer Glauber in dieser Zeit', which was soon to appear in the Bayerischen Israelitische Gemeindezeitung. ${ }^{22}$ Sharp, erudite, and with more than a touch of patronization, Scholem, an outspoken advocate for the liberation of Jewish forms of thinking for foreign Protestant

\footnotetext{
${ }^{21}$ Ludwig Feuchtwanger, "Jüdischer Glauber in dieser Zeit": Der Versuch einer neuen jüdischen Glaubenslehre", Bayerischen Israelitische Gemeindezeitung 11 (June 1 1932):165-7 [henceforth DV].

${ }_{22}$ Gerhard Scholem, 'Offener Brief an den Verfasser der Schrift 'Jüdischer Glaube in dieser Zeit' in Bayerischen Israelitische Gemeindezeitung 16 (15 August 1932): 241-4 (henceforth OB).
} 
presumptions, subjected Schoep's work to a blistering critique. David Biale considers Scholem's open letter to Schoeps "an antiexistentialist manifesto", but also, "a polemic against Barthian theology". ${ }^{23}$ Scholem had been a harsh denouncer of Jewish liberalism himself - to which he refers as "hybrid creatures of double-existence in self-deception" (OB 244) - yet in contrast to Schoeps, his own critique is conducted "without the Protestant terminology you have chosen, which for me is utterly reluctant" (OB 241). In this utterance, Scholem indicates that critique of the Protestant liberalist framework can be leveled from a Jewish point of view without resort to the equally alien and alienating Protestant terminology. In Scholem's mind, the overall Protestant tenor of Schoeps's way of thinking leads him away from what is essential to Judaism. Schoeps's desire to codify Judaism into a set of Dogmas and his "tendency towards actualization [Aktualisierung] of theological content of Judaism" illustrates that, following the liberal-Jewish impulse, he is "seduced into the transformation of Judaism into theology" (OB 242). Pointing to the incompatibility of the two, Scholem ironically remarks: "I very much strive for the former and thus reject the latter" (OB 242). In terms of actual content, Scholem singles out Schoeps's emphasis on the notion of 'creation out of nothing' as woefully inadequate. Deeply engaged with the category of nothingness [Nichts] himself, Scholem maintains that besides the fact that Schoeps ascribes to this 'nothing' too high a theological regard without taking into account its ambiguity and complicatedness, he is also is guilty of overlooking the simple fact that creation out of nothing makes no appearance in the bible at all. Indeed, Schoeps is equally unaware that the very conception of biblical theology "has never existed in Judaism, and not in vain".

Scholem finds Schoeps's "orientation toward Karl Barth and his dubious terminology" to be especially problematic for a theology flaunting the title of Judaism. One point derivative from the Barthian perspective is particularly inappropriate to Judaism: the downplaying of history implied in Barth's radical God-world opposition and revelation-centered theology cannot accommodate "tradition as an essential

${ }^{23}$ David Biale, Gershom Scholem: Kabbalah and Counter-History (Cambridge, Mass.: Havard University Press, 1982), 128-30, 195. Scholem's reconstruction of Kabbalistic traditions is itself an attempt, deeply rooted in the intellectual atmosphere of Weimar theology, to bring about an authentic Jewish revival. 
category of the religious way of life in Judaism," (OB 243) Scholem avers. Schoeps's deliberate neglect of the centuries-long accumulated Jewish knowledge and tradition and his retreat to an ahistorical biblical theology generates a neutralization and hence distortion of Jewish historical consciousness. The downright rejection of "the entire spiritual compilation [Komplex] of "Halakha"" (ibid) as theologically insignificant and "the repudiation of the question about the religious meaning of oral Torah and its basic concepts (tradition, commentary, question and inquirability [Erfragbarkeit])" (ibid) is simply incomprehensible from a Jewish perspective. Jewish existence and theology are situated and cultivated within actual history; placing the center of gravity on the suprahistorical is foreign to Judaism. ${ }^{24}$ Scholem also rightly identifies the downplaying of history and tradition entailed by the conflation of revelation and redemption, for which Schoeps - following Barth - advocates. He who aspires to remain within the boundaries Judaism "must also seek to travel the way that leads between these two poles" (OB 244). Inserting Barthian principles into Judaism subverts the legitimacy and value of tradition and its relation to the Word of God.

In Scholem's judgment, taking the heutigen Daseinsverständnis as Schoeps's point of departure for a biblical and revelation-centered theology reveals the arbitrariness of his endeavor. For from the perspective of the modern secular person, the written torah, witnessing to the biblical revelation, too "could be no less absurd than the idea enclosed by the heading 'oral torah"” (OB 243). On what basis does Schoeps think one is legitimate and necessary while the other obsolete? Schoeps's assumptions would lead him to the conclusion that in truth - "they are both obsolete" (ibid), but it is his "Protestant fixation" (ibid) and the sola scriptura principle that is at the root of his position.

This biblical fixation and its implied denial of tradition is interlinked, according to Scholem, to Schoeps's mistaken conception of revelation. To express this argument Scholem invokes an account of revelation he uncovered in his studies of Kabbalah, according to which revelation is in itself an event lacking any

\footnotetext{
${ }^{24}$ Krell, Intersecting Pathways, 50. The accusation of neutralizing history has been leveled against Barth already in the early 1920 s by Harnack. See note 3 .
} 
specific meaning; there is "no immediate, undialectic application of the divine word". ${ }^{25}$ It is only charged with meaning once it is translated into, or mediated through, human language (which is itself of divine origin) - "it becomes a comprehensible communication only when it is mediated" (ibid). In effect, commentary and tradition become, paradoxically, the condition of possibility of the very idea of meaningful revelation. Schoeps is so biblically-focused that he overlooks that the meaning of the Word of God is not readily present in scripture as he presumes. "Revelation is, for all its uniqueness, still a medium", says Scholem. "It is the absolute, meaning-giving, yet in itself meaningless that becomes interpretable [das Deutbare]" (OB 243). The meaning of revelation, Scholem affirms, "first unfolds itself in the continuous relationship to time, in tradition" (ibid). It is impossible to understand the meaning of revelation simply from its occurrence, detached from the continuous engagements and interpretations of tradition, thus manifesting the "absolute symbolic abundance" of God's Word. As "meaningless but meaning-bestowing", there is in fact "nothing in historical time [that] requires concretization more than the 'absolute concreteness' of the word of revelation" (ibid). ${ }^{26}$ The unfolding of God's Word in history through the mediation of tradition and commentary is implicit and essential to the very meaning of revelation. ${ }^{27}$ The Barthian account embraced by Schoeps whereby the Word of God is "meaningful in an unmediated (undialectical) way", would be, Scholem believes, "destructive". ${ }^{28}$ The Kabbalistic

${ }^{25}$ Scholem, "Revelation and Tradition as Relgious Categories in Judaism" in The Messianic idea in Judaism and Other Essays on Jewish Spirituality (New York: Schocken Books, 1971) 294-96.

${ }^{26}$ Biale, Scholem, 139.

${ }^{27}$ In his rejoinder to Scholem, who he considered his most astute critic, Schoeps suggested that Scholem represented what he dubbed an 'ontological-Catholic' tendency in Judaism which clings to tradition and history, while he himself represented a 'critical-Protestant' tendency which clings to revelation and faith. Schoeps, Ja-Nein-und Trotzdem, 45-54; Rückblicke: Die letzten dreißig Jahre (1925-1955) und danach (Berlin, 1963) 73; Biale, Scholem, 130. It is interesting to note that a critical assessment along similar lines has been made of Michael Wyschogrod's attempt to return to a 'biblical' construal of Judaism in a Barthian key. In his rejoinder to Wyschogrod's Jewish Barthianism, Shai Held writes as follows: "But contra Wyschogrod, Jewish theology has never been based on a direct encounter with scripture but, rather, on an encounter with scripture as read and interpreted by Jewish tradition: sola scriptura is, Jewishly speaking, an utterly alien idea. A theology that takes the oral Torah seriously is, in some critical sense, necessarily more Catholic than Protestant - in other words, it takes tradition at least as seriously as it takes scripture. Put differently (and perhaps more traditionally), a Jewish 'theology of the Word of God' must emphasize that the Word of God includes both the Written and the Oral Torah and that the former is consistently read in light of the latter". Shai Held, "The Promise and Peril of Jewish Barthiansim: The Theology of Michael Wyschogrod", Modern Judaism 25, no. 3 (October 2005): 316-26.

${ }^{28}$ In their famous correspondence, Walter Benjamin and Scholem briefly discuss the 'Open Letter'. "Even without being familiar with Schoeps's work", Benjamin writes, "I am in complete agreement that nothing is more necessary 
conception of revelation that Scholem assumes as his own is supplemented with the anti-dogmatic idea of the inexhaustible number of possible interpretations of the Word of God. "Infinitely many lights burn in each word" of the torah. ${ }^{29}$ This anti-dogmatic idea is the base of Scholem's charge that Schoeps, while outwardly rebuking liberal theology, is himself nourished from apologetic Jewish liberal theologians who construed a monolithic and dogmatic depiction of Judaism. Schoeps's account can hardly justify its purported name as 'Jewish theology'. If anything, it is a modern form of "Kierkegaardian" Karraiteism which "does not grant the long breath which Jewish existence needs" (OB 244). The dialectic of the Word of God in its multitude of manifestations in Jewish tradition is the heart of Jewish existence: "Do you" Scholem challenges Schoeps - "want to rip up the dialectic of our existence? No beginning [for a Jewish theology] could be nobler than that!" (ibid).

In this vehement critique, Scholem claims Schoeps endorsement of Barthianism to be futile by pointing to its foreign Protestant origin, its unsuitable dogmatic method, and also its specific content that undermines fundamental themes in Judaism. But what is worth noticing is that Scholem shares with Schoeps some significant motivations and assumptions, such as the repulsion from liberalism and a notion of the utter otherness of God. However he looks not to dialectical theology but to the tradition of Kabbalah in order to accommodate his theological concerns.

The neglect of history and tradition necessitated by the adoption of the Barthian framework in Schoeps is similarly noted by Rabbi Max Grünewald. Discussing Schoeps alongside Franz Rosenzweig and Martin Buber, Grünewald affirms Schoeps's attempt to establish foundations for a specifically Jewish theology as suitable for the times wherein "the duty of self-representation [...] is urgent" ${ }^{30}$ After the lingering liberal trend, the originality and radicalism of the young thinker is "a purifying thunderstorm". Indeed,

than to finish off those hideous pacesetters of Protestant theologoumena with Judaism. But that is a minor matter compared with the definitions of Revelation given in your text and held by me in high esteem: 'The absolutely concrete can never be fulfilled at all"'. The Correspondence of Walter Benjamin and Gershom Scholem 1932-1940, ed. Gershom Scholem, trans. Gary Smith and Andre Lefevere (New York: Schocken Books, 1989) 28.

${ }^{29}$ Gershom Scholem, "Reflections on Jewish Theology", in On Jews and Judaism in Crisis: Selected Essays, ed. Werner J. Dannhauser, (New York: Schocken Books, 1976), 268-70.

${ }^{30}$ Rabbiner Dr. Max Grünewald, "Wege zu eine jüdischen Theologie", Frankfurter Israelitisches Gemeindeblatt 12, no. 1 (September 1933): 3-5 (henceforth WT). 
"no one is like him in the position to differentiate between top and bottom, between the Word of God and human affairs [Tun]". Grünewald notes the mark of "the literal interpretation of the bible [Wort-Verstand] of dialectical theology" on Schoeps's monograph, and agrees, unlike Scholem, that dialectical theology can be a legitimate source for the production of a Jewish theology. Yet Schoeps is misguided as to the suitable content and extent of this application. A major deficiency in his work, Grünewald holds, is the absence of any attempt "to determine the historical-suprahistorical relation of God and people. The history of participation, the tradition, thus, is not recognized" (WT 3). Schoeps wants to plunge back into an ahistorical biblical revelation, however "between the biblical word and the 'today' is missing the connective, the inside of Judaism, representing not the Heilsgeschichte but the tradition."(WT 4) Thus Grünewald determines: "It becomes apparent: the arm of the dialectical theologians is too short" (ibid). The general theological impetus animating dialectical theology is one that Judaism would be wise to emulate, he claims, yet it must blaze its own path in the much needed development of a Jewish theology because the specific Barthian implementation arrives at some unacceptable positions.

A particularly striking critique of Schoeps's effort for a Jewish Barthianism was leveled by Eduard Strau $\beta$, the chemist and Jewish educator. ${ }^{31}$ Schoeps's book is indeed "an important book" (EJ 314), he agrees, yet it is stained by essential flaws. So often, Strau $\beta$ laments, echoing Feuchtwanger, foreign intellectual frameworks are imported to solve the challenges of the Jewish spirit. This is clearly true of Schoeps: "obviously the source of teaching from which this unjewish-Jewish theologian draws is the Christian "dialectical theology" (EJ 313). In so doing, Schoeps reveals his underlining assumption: "because the sickness of all men does not spare us, why should the same means not also help us?" (EJ 312). Inasmuch as the modern Jew and Christian are both undergoing a similar spiritual crisis, then presumably the same solution will be equally effective. Strau $\beta$ finds this assumption faulty - Schoeps's diagnosis of the Jewish condition is conducted according to "Christian problematic and method", and thus depicts the Jewish situation as "under precisely the same threat as Protestant theology [...] namely in the

${ }^{31}$ Eduard Strau $\beta$, “Eine jüdische Theologie?” Der Morgen 4 (October 1932): 312-4 (henceforth EJ]. 
lack of faith [Glaubenlosigkeit]" (EJ 313). In particular, Schoeps adopts the Christian structure of existential transformation whereby one is born a heathen and must become a Christian, and forces it onto the Jewish case: the modern-secular Jewish person is a heathen who must become a Jew. As stated, for Schoeps the moment of revelation involves existential salvation - what he called teshuvah. Yet this Christian framing cannot be transposed into a Jewish key because in Judaism faith does not have the constitutive role it has in Christianity, where "Christianus fit, non nascitur [one is not born a Christian, but rather becomes one]". The heathen person becomes Christian through faith" -yet "what corresponds to this is the Jewish world?" (ibid). This point is a particularly penetrating one, for Strau $\beta$ does not focus on the more readily available themes in dialectical theology of divine transcendence or revelation, but rather uncovers the structure of the religious selfhood, and by implication the account of repentance it implicitly promotes, only to then contrast it to the Jewish outlook. "The Jew", comments Strau $\beta$, "was and is occupied at all times with the concrete reminder that $[\ldots]$ his people, to whom he belongs indissolubly and to whom he can return home from the farthest and most remote way of life [Lebensgestaltung], have become God's people in an hour of historical revelation" (EJ 313). In Christianity, one begins as a heathen - fallen, godforsaken, lost, and by opening oneself to God, becomes a Christian - salvaged, redeemed, found. Conversely, Strau $\beta$ notes, the Jew is always already a Jew; one's spiritual trajectory is not that of either/or, but moves on the axis of more or less, closer or farther. ${ }^{32}$ In Judaism, teshuva is a transition in degree. The existential structure exhibited in Schoeps's scheme is rooted in that of the "new 'theology of crisis' [...] wherein men like Karl Barth, Emil Brunner and Friedrich Gogarten offer their co-religionists aid against the reemergence of heathenism", and it is "precisely this theology with its Christian-eschatological character that Schoeps wants to bring to contemporary Jews" (EJ 314). However the Jew "does not require" (ibid) it. The Barthian position of salvation as concomitant to the knowledge of God, understood as faith, is in discord with the Jewish view whereby knowledge of God, understood as obedience, is an essential yet partial step on the path to

\footnotetext{
${ }^{32}$ Barth's either/or position is stated explicitly, for example, in his response to Harnack: "the way from the old to the new world is not a stairway, not a development in any sense whatsoever; it is a being born anew." Rumscheidt, Revelation and Theology, 34.
} 
salvation. Schoeps, according to Strau $\beta$, diagnosed the Jewish spiritual predicament with an inadequate set of assumptions and thus inevitably reaches a wrong diagnosis and an improper antidote. The significant point that Strau $\beta$ directs attention to is that the structure of the religious selfhood undergirding Barth's framework reflects an inherently Christian set of assumptions that ultimately determine Barthianism to be ill-fitted for Jewish purposes and compromises the uniqueness, indeed particularity of being-Jewish.

It is clear that the overall Jewish response to Schoeps expressed a profound discontent for what was seen as an attempt to mold a Jewish theology from an overtly un-Jewish template - to Christianize Judaism. Tellingly, Christian reactions correspondingly disapproved of what they perceived as his Judaizing Barth's Christian scheme. Barth himself found Schoeps's invocation of his categories in the service of Jewish theology "fundamentally strange". ${ }^{33}$ By drawing so deeply on his theology, Schoeps provides a “'Jewish teaching of the 'Fall', 'original sin', 'divine likeness after the Fall', and justification”. Yet in Barth's supersessionist view, any Jewish theology, especially one which draws on his own thinking, "must culminate in the proof that Christ had been crucified" - and yet Schoeps does not take that final and necessary step. Barth, like Schoeps's Jewish detractors but unlike Schoeps himself, can make no sense of 'Jewish Barthianism'. The particularity and truth of Christian faith resists the neutral migration of its specific dogmas to other religions. For him, therefore, Schoeps's partial Jewish appropriation is not 'poor' Barthianism, but not Barthianism at all.

While agreeing with the judgment that Barth's theology is inapplicable for Jews, Rev. George L.B. Sloan nevertheless found that it can play a constructive role in their eventual conversion to Christianity. In this respect, he notes, Schoeps's work is beneficial: "his sharp, deep criticism of the superficiality of philosophy of religion and of the humanist Enlightenment optimism will [...] have a very salutary effect

\footnotetext{
${ }^{33}$ Gary Lease, "Der Briefwechsel zwischen Karl Barth und Hans-Joachim Schoeps", Menora, Jahrbuch für deutschjüdische Geschichte 2 (1991): 105-37. Barth does however reference favorably to Schoeps's Jüdischer and his Jüdisch-christliches Religionsgespräch in neunzehn Jahrhunderten (1937) in his Kirchliche Dogmatik, § 14 Die Zeit der Offenbarung (Zollikon: Evangelische Verlag, 1938).
} 
on Jewish thought, and may even form a valuable Praeparatio Evangelica for the Jews. But all this lies still in the future". ${ }^{34}$

\section{Alexander Altmann}

Concurrent to Schoeps's construction of suitable foundations for a Jewish theology, an equivalent effort was undertaken in the Orthodox camp by Alexander Altmann, then a young rabbi who pursued the task to establish Jewish orthodoxy on firm philosophical grounds. ${ }^{35}$ Fed up by what he found to be the problematic character of nineteenth century theological heritage, also Altmann sought to establish a Jewish theology based on divine transcendence, autonomy of religion, and revelation. That Altmann was intrigued by dialectical theology is apparent by the fact that between 1933 and 1935 he addressed the theme of dialectical theology and Judaism in at least four separate occasions. In his essay "Was ist Jüdische Theologie? Beiträge zur jüdischen Neuorientierung" (1933), Altmann discusses and evaluates Wiener's and Schoeps's use of Barthian conceptions and presents an alternative account of Jewish theology. ${ }^{36}$ Accepting Barth's distinction between theology and all other intellectual endeavors, Altmann appreciates the turn to theology issued by Schoeps as a praiseworthy divergence from the general orientation towards philosophy of religion in modern Jewish thought. Altmann credits Schoeps "influenced primarily by 'dialectical theology" - for moving "revelation, grounded in God's transcendence, to the center of Jewish consideration" (JT 41). This noteworthy theological accomplishment is achieved, however, despite "the radical inappropriateness of his enterprise in its details". Schoeps's main shortcoming lies in his neglect of addressing the fundamental particularity of Jewish existence: unlike philosophy of religion, "theology must always be conscious of its particularistic

${ }^{34}$ G.L.B Sloan, "Das Problem der Judenmission und die Dialektische Theologie", Theologische Aufsätze: Karl Barth zum 50. Geburtstag (München, Chr. Kaiser Verlag, 1936), 521-2.

${ }^{35}$ Thomas Meyer, Zwischen Philosophie und Gesetz: Jüdische Philosophie und Theologie Von 1933 bis 1938 (Brill, 2009), 107-165.

${ }^{36}$ Alexander Altmann, "Was ist Jüdische Theologie? Beiträge zur jüdischen Neuorientierung", Der Israelit (summer 1933). An expanded version was republished later that year. Translated to English as "What is Jewish Theology?" in: Alexander Altmann, The Meaning of Jewish Existence, Theological Essays 1930-1939, ed. Alfred L. Ivry (New Hampshire: Brandeis University Press, 1991), 40-56 (henceforth JT). This English translation is used unless otherwise noted. 
character" (JT 52). Altmann insists, like Strau $\beta$, that the existential trait of the secular Jew is still stamped by a specifically Jewish mark, and hence dissimilar to the general western person. And like Wiener, Altmann contends that a Jewish theology must focus on the particular significance of revelation and peoplehood as "the two sufficient and not further reducible elements". The analysis of these two phenomena reveals the true character of Jewish theology and its distinctiveness from Christian theology. In his "taking dialectical theology over wholesale, and wholly uncritically" (JT 47), Schoeps has committed some deeply problematic missteps. For one, Christian theology as a whole "receives its characteristic function through reference to the sacral authority of the church". This is true even with respect to Barth's theology, which "no matter how strongly it is, ideally, related to revelation - remains directed, in fact, toward the institution of the church, the producer and bearer of the charismatic pneuma" (JT 43). Judaism lacks this kind of mediating institution, and in its stead "the people, and not the church, are the unmediated bearers of historical revelation" (JT 44). Furthermore, the doctrine of opposition, underscored by Kierkegaard and taken to its utmost extreme by Barth, is not "merely a logical dialectic", i.e., the conclusion of neutral theological contemplation, but is in fact "based in the Christian doctrine of Original Sin [Sündenfall]" (JT 47). The infinite disjunction between man and God is an outcome and reflection of the Christian distinction between the fallen human being inherently stained by the Original Sin and the benevolent God. Altmann, identifying the deeply Calvinist tone of Barth's position, dubs this "the indissoluble difference between Jewish and dialectical Protestant theology". That Wiener overlooked this crucial point caused him to mistakenly equate it to the unknowable God of the docta ignorantia tradition championed by Maimonides. This is a crucial point, one which reaches to the heart of the Jewish dilemma vis-a-vis Barth's theology. For by disclosing that his position of radical divine transcendence is not logically deduced but rather the result of a dogmatic commitment, Altmann indicates that no distinction could be made with respect to neutral and Christian elements in Barthianism. If Judaism seeks to develop a theology founded upon a robust notion of divine otherness, therefore, it should not look to dialectical theology for assistance. The sources to do so should to be found within its own tradition - and 
Altmann identifies this source in the thought of Maimonides. ${ }^{37}$ Yet unlike Wiener, it is crucial for Altmann to distinguish Maimonides' conception of divine transcendence from Barth's - the former constitutes a major milestone in the Jewish war against idolatry, while the latter is an outcome of Christian dogmatics. The tacit confrontation between Barth and Maimonides exhibits how in certain Jewish intellectual circles the great mediaeval sage served as a prominent source for addressing the contemporary theological predicament that their Christian counterparts found in the Swiss theologian and his movement. ${ }^{38}$

For Altmann, revelation is of utmost importance for Jewish theology; not revelation as such, but a specific understanding of revelation, i.e., commandments and law: "Only a theology standing in relation to revelation and, at the same time, having halakha at its center is entitled to be called Jewish theology" (JT 46). In this respect, Wiener's account of Jewish Barthianism is significantly preferable to Schoeps's. Altmann lauds Wiener for asserting the particularistic nature of Jewish law and the essentiality of Jewish peoplehood for Jewish theology. But he also rebukes Wiener's view of the unbridgeable gap between the particularity of halakha and the universality of its theological and moral conceptions. Jewish theology, Altmann insists, "is completely homogenous" because it is completely particularistic. Schoeps on the other hand errs not only in his neglect and disregard of the Jewish concept of revelation as law but also in attempting to articulate the primal foundation of a Jewish theology in the form of dogmas and doctrines. Although there is place for a fluid, dynamic form of systemization, "Jewish theology is fundamentally not a systematic-literary labor but an actualistic-decisional function". Holding the view of revelation as law means that it originates in God and is prompted by divine will alone, but human beings nevertheless do have a role in its unfolding: divine law requires interpretation and implementation over time. Also taking

\footnotetext{
${ }^{37}$ Cf. for example Alexander Altmann, "Metaphysik und Religion", Jeschurun: Monatsschrift für Lehre und Leben im Judentum 17, no. 9-12 (1930): 321-47.

${ }^{38}$ A schematic account of the prominent role Maimonides played in Jewish-German intellectual circles at the time can be found, for example, in Alfred L. Ivry, "Hermann Cohen, Leo Strauss, Alexander Altmann: Maimonides in Germany", in The Trias of Maimonides: Jewish, Arabic and Ancient Culture of Knowledge, ed. Georges Tamer (Walter de Gruyter: Berlin, 2005), 175-83. The suggested connection between the theological temperament within which dialectical theology emerged and the intensified gravitation towards Maimonides among some Jewish thinkers is not mentioned by Ivry and constitutes a worthy topic for further scholarly elaboration.
} 
into account the gravity of the Jewish people as the bearers, interpreters and advancers of revelation implies a shared and continuous conception of the revelatory act. Revelation in Judaism is, Altmann stresses, dynamic: "the work of revelation is essentially uncompleted and is demanded anew historically each day". Altmann thus presents a theological account wherein revelation is accentuated while it is consciously and markedly un-Barthian and particularistically Jewish.

Building on his 1933 rejoinder to Schoeps and Wiener, Altmann's most systematic and direct engagement with dialectical theology takes place in a 1935 essay entitled "Zur Auseinandersetzung mit der dialektischen Theologie". ${ }^{39}$ Here allusions are made to texts by Gogarten and Brunner, but the main theological work addressed is Barth's Die christliche Dogmatik im Entwurf (1927). ${ }^{40}$ This essay reflects both the seriousness with which Altmann grappled with the Barthian challenge and his deep familiarity with the writings of the theologians associated to dialectical theology. Altmann also added to it an appendix dedicated to Schoeps, "Barth's Jewish student". ${ }^{41}$ Ultimately, Altmann aims to demonstrate here the deep discrepancies between the Barthian scheme and Judaism as he perceives it. Altmann's position is perfectly captured in his assertion that despite an "affinity of problems considered by these theologies" (DT 77) of Judaism and Christianity, the use of common theological language is frustrated due to "the presence of substantial structural differences". Altmann admits in the appendix that from a Jewish point of view, "there is no question we can learn a lot from Barth" (AP 359). Specifically, it is "the strictness with which theology is called back to itself", and the manner in which it "direct[s] its temporal spiritual powers to the word speaking only to it, also speaks to our conscience" (ibid). Yet the disposition toward the seriousness and autonomy of theology can only serve as a wake-up call for Jewish theologians to take hold of their own tradition; other than this general disposition, dialectical theology has little to offer.

\footnotetext{
${ }^{39}$ Alexander Altmann, "Zur Auseinandersetzung mit der dialektischen Theologie", Monatsschrift für Geschichte und Wissenschaft des Judentums 79 (1935): 345-61. In English: "A Discussion with Dialectical Theology", Altmann, Jewish Existence, 77-87. Auseinandersetzung also has the connotation of 'confrontation', 'argument'.

${ }^{40}$ Karl Barth, Die christliche Dogmatik im Entwurf, Erster band: Die Lehre vom Worte Gottes (Munich, 1927). Barth soon abandoned this project in favor of his Kirchliche Dogmatik.

${ }^{41}$ The appendix was not translated to English. See: Altmann, Auseinandersetzung, 358-61 (henceforth AP).
} 
The heart of the incompatibility of Judaism and dialectical theology lays in the strict disjunction between God and the world. "Is the thesis of opposition acceptable to a Jewish consciousness? [...] Is the Jew, too, as a member of the secularized world, subject to this distance from God? Is Kierkegaard the prototype of today's Jew also?" (DT 79). Altmann resolves definitely that "we cannot accept this on the basis of Jewish consciousness" (DT 78). Barth clearly rejects the bitter fruits of his theological predecessors, but "in order to overcome historicism Barth completely removes revelation from history" (DT 85). This position is completely unacceptable from a Jewish outlook: rejecting historicism does not demand the devaluation or disqualification of history. In Barth "temporality is sacrificed to eternity", and thus his idea of 'primal history' [Urgeschichte] - according to which "revelation is neither a part nor a predicate of history, nor does it pass over into history, even in the event of revelation itself", negates the Jewish perception of history as a worthy arena of human-God encounter. Barth's anti-historical attitude towards revelation possesses "a transcending, apocalyptic attitude", while "actual history" within which Judaism as "the continuity of a life lived according to Torah" (DT 86) operates, "cannot immediately be touched by this attitude" (DT 82).

For Altmann, the covenantal relationship between God and Israel cannot be fathomed through the prism of a radical demarcation of God and the depreciation of man. Barth's attempt to protect the purity of God from the blight of humanity professes a negative opinion of man and the world to which Judaism cannot concede. In the Jewish worldview "no dialectic of opposition is able to prevent man's being true to himself [...] God and man encounter each other, but God does not suspend human existence after creation by addressing it in revelation. How could this be thought, if man is really and truly God's creature, created in his image?" (DT 80).

It should be noted that by evoking the notion of imago dei, Altmann situates Judaism on the 'Catholic' side vis-à-vis the Protestant impulse towards divine-human opposition, epitomized in dialectical theology. The Jesuit Erich Przywara, whose thought occupied Altmann at the time, chided Barth for expounding an 
"extreme either-or between earth and heaven". ${ }^{42}$ By emphasizing the creatureliness of the human being, Przywara's theology stressed that the transcendent divine is both 'in us' and 'above us' ["Gott in uns und über uns"]. ${ }^{43}$ Altmann was well aware that his position bore semblance to Przywara's Catholic position. Articulating the Jewish position on history, Altmann contrasts the church, which "stands only outside of history" (DT 83) with Israel, which "stands within history and, at the same time, above history". And in a review of the first part of Przywara's systematic work Analogia entis (1932), Altmann explicitly notes that the principle of creatureliness espoused by Orthodox Judaism "is in truth not at all in such contrast, perhaps the principle is even identical, to the Catholic metaphysics of creatureliness postulated by Przywara". And both are contrasted in this review to "dialectical theology with its devaluation of the creaturely" ${ }^{44}$ Altmann also speaks of "the doctrine of an analogia entis between God and man, a doctrine that is decisive for the basic attitude of Jewish theology" (JT 46). Alongside the evident proficiency in Christian theology and the astute understanding of the figures and stances participating in the major theological dispute of the day, what is noteworthy here is that Altmann does not seem troubled with coupling these "basic" Jewish attitudes with the Catholic principle of creaturliness and analogia entis. By contrast, he observes in the appendix that Schoeps's commitment to Barth and acceptance of the doctrine of opposition is admittance to the Christian Fall and its implication that "the quality of creation is threatened". "It need not be said", he notes, "that for the Jewish consciousness the quality of creation as such is never dispensable" (AP 361).

The tendency toward abstraction, dogma and systemization of theology is opposed in Altmann's view to the concept of revelation as "law, teaching, torah". Moreover, the unavailability of the Word of God in

\footnotetext{
${ }^{42}$ Erich Przywara, Das Geheimnis Kierkegaards (Munich: Oldenbourg 1929), 30. Barth was accused of Marcionism by some of his contemporaries, most notably by Harnack, Rumscheidt, Revelation and Theology, 37. See also: Erich Foerster, "Macionitisches Christentum", Die christliche Welt 35, no. 45 (1921): 811; Arnold Hein, "Moderner Marcionitismus und praktische Theologie", Theologische Blätter 32, no. 6-7 (1922): 148. Barth ultimately rejected these accusations. Barth, Romans, 13, 47, 241-42; Rumscheidt, Revelation and Theology, 50, 95-100.

43 For instance: Erich Przywara, "Gott in uns und über uns? (Immanenz und Transzendenz in heutigen Geistesleben)", Stimmen der Zeit 105 (1923): 343-62; Przywara mentions Schoeps and his Barthian tendencies in his "Theologie des Judentums: Umschau", Stimmen der Zeit 124 (1933): 341-2.

${ }^{44}$ Alexander Altmann, "Zwischen Philosophie und Theologie: Drei Buchbesprechungen”, Der Israelit, no. 14/15 (7 April 1933): 1-2. Here Altmann also reviews J.C Franken's Kritische Philosophische und dialektische Theologie (1932).
} 
Barth's scheme is incompatible with the role of Jewish practice, halakha, in the heart of Jewish life. Similarly Barth's contention that an act of existential decision is required for the Bible to become testimony of the incarnation of the logos is problematic. The "shock readiness and decision" which is implied in Barth's attitude cannot sustain Jewish law. "Decision is like a dot", muses Altmann, but "action means extending into time; it is a path. Hence the law must be present. It is not an existential shock but existential familiarity". Thus the Word of God as law cannot be given "in the instability of decision" or in an "isolated timeless act of existential shock". Rather the Jewish perception of teshuvah "is the unique act of entering upon a path, of reconnecting to the continuum of history" (DT 87).

\section{End Note}

The disputed episode of explorations into a purported Jewish Barthianism is evidently situated within the fateful Jewish predicament of interwar Germany and its suggested solutions. As stated, it reflected the effort for Jewish self-assertion and the search for an authentic self-explication, with the backdrop of the disassociation with the liberal worldview and its the hopes for acceptance in German culture, the so-called 'German-Jewish synthesis'. Indeed, the episode of Jewish Barthianism manifests the intricate interdependence of the theological and the political: Wiener's proclamation of the Jewish peoplehood as a foundation to any Jewish theology worthy of the name - exceptional in the environment of liberal Judaism at the time - implied a rejection of the allegiance to the German Volk and bespoke his Zionistic dispositions. $^{45}$ The interweaving of theology and politics is blatantly apparent in Schoeps, whose conservative reactionary convictions and attribution of religious significance to German nationalism saw in the liberalism of Weimar Republic an offence against God, to which the Jewish adaptation of dialectical theology may serve as an antidote. Schoeps even founded an anti-liberal, fervently patriotic Jewish movement 'Der deutsche Vortrupp, Gefolgschaft deutscher Juden', envisioned as the spearhead of

\footnotetext{
${ }^{45}$ Schine, Jewish Thought Adrift, 109-20; Wiener, Jüdische Religion, 258-74.
} 
the political and religious revolution in which he believed. ${ }^{46}$ The critical reception of Schoeps's theology among his fellow Jews is no doubt entwined with the overarching hostility towards his fascist political views. ${ }^{47}$ Altmann's emphasis on the particularity of revelation as Jewish law and Jewish peoplehood serves as the theological underpinning of his Religious Zionism. Similarly, the responses of Feuchtwanger, Strau $\beta$ and Grünewald are also to be seen in light of their efforts for constituting proud Jewish identity and existence in times when these could hardly be taken for granted. In this respect, Barth's debunking of human initiative and the handing over to God all hope for salvation was at odds with any and all of the political positions and endeavors that hoped to actively ameliorate the Jewish predicament.

Yet above all, the Jewish debate over the possible bearings of Barthianism on Judaism manifests the complicated nature of the theological relations between Judaism and Christianity. The Jewish engagement with dialectical theology is marked by fascination and disapproval, influence and rejection, adoption and adaptation. Barthianism was seen as a model or source of inspiration for Jewish renewal, but at the same time as the doctrinal opposition in contrast to which Judaism can best affirm itself. Overall is can be said that in the period when the force and challenge of Barth's theology was most critical, Jewish thinkers made thoughtful and compelling arguments against its appropriateness. As we have seen, the motivation to uphold the complete otherness of the divine and recover the radical difference between God and humanity, so disturbingly compromised by the nineteenth century theological framework, was shared by Karl Barth and Jewish theologians. Yet the radicalism through which Barth undertook this task of

\footnotetext{
${ }^{46}$ On Schoeps and the Vortrupp: Carl J. Rheins, "Deutscher Vortrupp, Gefolgschaft deutscher Juden 1933-1935", Leo Baeck Institute Year Book XXVI (1981): 207-29; George L. Mosse, German and Jews: The Right, the Left, and the Search for a 'Third Force' in Pre-Nazi Germany (London: Orbach \& Chambers, 1971), especially 102-9; Lease, Odd Fellows, 225-6; John V. Dippel, Bound upon a Wheel of Fire: Why So Many German Jews Made the Tragic Decision to Remain in Nazi Germany (New York: Basic Books, 1996), 106-7.

${ }^{47}$ For instance: Ignaz Maybaum's 'Rezension' of Schoeps's “Wir deutschen Juden”, Der Morgen 5 (August 1934): 241-2. This is especially discernable in Scholem's 'Open Letter'. Also, reporting to Benjamin upon meeting Schoeps, Scholem describes him as "bursting with vanity and the desire to be on everybody's lips"; he "is so busy trying to connect up with German fascism in every way, sans phrase [without further ado], that he will not have time for any other activities in the foreseeable future" (Scholem, Correspondence, 31). Benjamin's response reveals similar sentiment: "I was quite delighted to read what you had to say about Schoeps [...] The upshot: there is order in the world. And the Schoepses are looked after - if not by God, then by Satan" (ibid., 36).
} 
theological reform could not, ultimately, be shared by his Jewish counterparts. While Barth took his critique of liberalism to its ultimate conclusion, the overall Jewish tone, as exhibited by Wiener, Altmann, and the numerous responses to Schoeps, was a theologically-motivated refusal to allow the tension between history and theology to become a full-fledged rift, nor were they willing to embrace, as a reaction, principles alien to their understanding of Judaism. They confirmed a stark account of divine transcendence, albeit one which does not disable the relational character of God with the world, humanity and history.

This seemingly clean cut story of a distinctive and defining boundary line beyond which Judaism would not concede must however be problematized: firstly, because as mentioned it nevertheless involves a shared rejection of liberal positions by both Jews and Christians as well as a similar signaling toward a theocentric theological response, thereby substantiating rather than undermining their joint theological horizon. Secondly, because what surfaces from the Jewish grappling with Barthianism is how some of the Christian movement's theological precepts resonated with familiar notions found within Jewish tradition itself. The turn to Maimonides by Altmann and Wiener and to Kabbalah by Scholem (and perhaps also Schoeps's construction of an anti-Maimonidean irrational counter-history) to counter Barthianism illustrate not only the desire to address the contemporary theological challenges out of the sources of Judaism, but also the complex way in which Barth became particularly relevant in the context of Jewish modernity, so that these Jewish sources were seen as bearing comparable theological content with Barthianism without its undesired Christian 'baggage'. ${ }^{48}$ But more importantly, this clean cut story must be problematized because the outlined theological motivations behind the Jewish refusal of Barthianism correspond to some significant internal critiques of dialectical theology's radicalism within Christian circles themselves. This was already indicated through the Przywara - Altmann connection where the desire to distance Judaism from Barthianism resulted in the surprising bed-fellow of Catholicism. But

\footnotetext{
${ }^{48}$ In this respect, Franz Rosenzweig's response to Karl Barth and how Jews at the time understood the many affinities between these two thinkers is another case to point. On this see my forthcoming "Franz Rosenzweig and Karl Barth: A Chapter in the Jewish Reception of Dialectical Theology" Journal of Religion 96 no. 4 (January 2017).
} 
dialectical theology also spurred much protest within Protestant circles, which were deeply disturbed by similar issues that Jewish thinkers found unacceptable. Liberal theologians and even some of Barth's theological companions ultimately found the unbridgeable abyss between God and world and the onesidedness of the divine-human dialectic incompatible with the overall Christian message. ${ }^{49}$ The Jewish resistance to dialectical theology is therefore comparable in some important respects to internal Christian voices of opposition.

We argued above that the overarching question regarding the universality and neutrality vs. the particularity of theological concepts undergirds this theological encounter as a whole. The varying answers to this question expressed in our discussion manifest not only the diverse theological assumptions, but also how Barthianism came to mean different things for different thinkers in a way that encompasses their concerns over the possibility of Jewish self-assertion vis-à-vis Christianity. Thus the highly paradoxical investigation into the possibility of Jewish Barthianism serves as a prime example of the way in which Jewish-Christian difference is constructed in the modern world.

\footnotetext{
${ }^{49}$ A concise description of this Christian response can be found in Gary Dorrien, The Barthian Revolt in Modern Theology (Louisville: Westminster John Knox Press, 2000).
} 